\title{
STATUT QUO TECHNICAL EDUCATION BY COMPUTER - CONTROLLED MACHINES AT PRIMARY SCHOOLS AND SECONDARY SCHOOLS
}

Pavel MOC* , Fakulta pedagogická Západočeské univerzity v Plzni, Česká republika

Přijato: 25. 5. 2020 / Akceptováno: 5. 1. 2021

Typ článku:Výzkumný článek

DOI: $10.5507 /$ jtie.2021.002

\begin{abstract}
The aim of the work is to research the attitudes of students to technical education and their influence by teaching focused on computer-controlled machines (e.g. milling machines, engravers, 3D printers). The prerequisite for the research is the creation of a research study, which will secure an overview of the researched issues at the present moment. The study itself first focuses on defining keywords, both in Czech and in English. Next, appropriate sources are sought and divided into domestic and foreign. The result is an analysis of each source with a short summary of the source. Finally, all sources are summarized in the final report, which points to the fact that, especially in the world, education of programmable machines is already being implemented. Suitable procedures and examples are finding. On the contrary, the situation in the Czech Republic is at the beginning of its introduction into educational processes.
\end{abstract}

Key words: machines, science, matematics, 3D Milling Machines, CNC Mills in the classroom, CNC cutter in the classroom, Pre-College Engineering Education.

\section{SOUČASNÝ STAV TECHNICKÉHO VZDĚLÁVÁNÍ POMOCÍ POČÍTAČEM ŘÍZENÝCH STROJŮ NA ZŠ A SS̆}

\begin{abstract}
Abstrakt: Cílem práce je výzkum postojů žáků k technické výchově a jejich ovlivnitelnost výukou zaměřenou na počítačem řízené stroje (frézky, gravírky, 3D tiskárny). Předpokladem vlastního výzkumu je vznik přehledové studie, jež zajistí přehled zkoumané problematiky v současném stavu doma i v zahraničí. Vlastní studie se nejdřive zaměřuje na definování kličových slov, jak v českém, tak i v anglickém jazyce. Následně jsou vyhledány vhodné zdroje a rozděleny na domácí a zahraniční. Výsledkem je analýza každého zdroje s krátkým abstraktem zdroje. Na závěr jsou všechny zdroje shrnuty ve výslednou zprávu, jež poukazuje na skutečnost, že především ve světě je vzdělávání v oblasti programovatelných strojů již zaváděno. Jsou hledány vhodné postupy a príklady. Naopak situace v ČR je na počátku zavádění do vzdělávacích procesů.
\end{abstract}


Klíčová slova: stroje, technika, algoritmizace, 3D tiskárna, CNC soustruh, CNC frézka, vzdělávání na základních školách.

*Autor pro korespondenci: pavelmoc@kvd.zcu.cz

\section{1 Úvod}

Programování počítačem řízených strojů je $\mathrm{v}$ dnešní době spíše záležitost odborných, technicky zaměřených středních škol, kam je $\mathrm{v}$ rámci přípravy na budoucí povolání toto učivo zařazováno. $\mathrm{V}$ následujících letech lze ovšem předpokládat značný rozmach robotizace nejen $\mathrm{v}$ průmyslu, ale i v běžném životě. Základem rozmachu robotizace jsou v zásadě dvě věci - vhodná řídící a senzorická technika, kterou dnes již disponujeme a za druhé potenciál, který je založen na vhodných mechatronických částí, jež dokáží nahradit jemnou lidskou motoriku. V druhém př́padě bude pravděpodobně ještě několik let vývoj trvat, ale lze předpokládat, že nejdéle v následujícím desetiletí začnou stroje nahrazovat spoustu dalších lidských činností.

Již dnes jsme svědky toho, jak je mnohdy člověku nebezpečná práce nahrazována roboty. $Z$ výše uvedeného vyplývá, že je potřeba připravit mladou generaci na vědeckotechnický růst v oblasti člověkem řízených strojů - robotů.

Otázkou zůstává, zda programování počítačem řízených strojů vyučovat již na základní škole nebo celou tuto problematiku ponechat na odborných středních školách.

Cílovou skupinou výzkumu budou žáci základních a středních škol při výuce technicky zaměřených předmětů $\mathrm{v}$ oblasti elektrotechniky a automatizace se zaměřením na programování průmyslových automatů - počítačů, jež řídí stroje - roboty, manipulátory.

Základní otázkou, na kterou se budu snažit taktéž najít odpověd', zůstává, zda pro nadcházející populaci je potřeba zaměřit se na programování strojů již na základní škole nebo zda ponechat tuto problematiku až na střední odborné školy. Prozatím se domnívám, že s výukou programování počítači řízených strojů by se mělo začít co možná nejdříve, tzn. na základní škole, nebot tím se zvyšuje šance na objevení technicky zaměřených talentů $\mathrm{z}$ řad žáků základních škola a zároveň se tím zvyšuje i motivace.

Je více než pravděpodobné, že následující generace budou nuceni strojům více porozumět a dokázat je ovládat. Nemusí se nutně jednat pouze o výrobní 
prostř̌edky, ale i v domácnosti, kde jsme již z části obklopeni domácími spotřebiči, které nepostačí jen „zapnou a vypnout“, ale bude potřeba s nimi jistým způsobem komunikovat, zadávat povely, ř́dit je - programovat. Vzhledem k tomu, že dnes nelze předpokládat umělou inteligenci na úrovni člověka, bude vždy zadávání úkolů - algoritmus záviset na přesném zadání člověkem.

Ačkoliv se mnohým lidem může jevit, že dovednosti v oblasti programování získá žák až na technicky zaměřené stř̌ední škole, začíná se stále více jednat o tom, zda je nutné s podobnou výukou začít již na základní škole. Samozřejmě s tím je spjata i př́padná úprava RVP, protože časová dotace v technické výchově na druhém stupni je omezena. Následně by bylo potřeba stanovit priority s následným rozsahem konkrétních vyučovaných oblastí.

Za hlavní přínos práce můžeme považovat navržení metodiky pro výuku programování a práce s počítačem řízených strojů již na základní škole a její ověření v praxi. Toto považujeme za velmi důležité, nebot by se mnozí žáci mohli již $\mathrm{v}$ raném věku na základě získaného zájmu rozhodnout pro studium technických oborů na středních školách.

V následujícím výzkumu se též pokusím odpovědět na následující otázky:

- Bude přínosné zavést výuku programování a práci s počítačem řízenými stroji již na základní školu, nebo je lepší ponechat programování strojů na odborné stř̌ední školy?

- Již dnes se na SŠ s technickým zaměřením vyučuje programování PLC automatů, ale rozhodně se výuka nezaměřuje výlučně na tuto oblast. Má se tento stav ponechat nebo vytvořit studijní programy zaměřené na programování počítačem řízených strojů?

- Ř́zením a programováním výrobních celků se dnes věnují vybrané studijní programy na úrovni terciálního vzdělávání. Je otázkou, zda se této problematice věnovat $v$ určité omezené podobě i na SŠ, případně ZŠ?

Závěrem lze říci, že algoritmizace, dovednost chápat pracovní postupy strojů se schopností jejich programování - řízení, by měla být při nejmenším zkoumána s ohledem na předpokládaný budoucí technologický rozvoj v oblasti počítačem řízených strojů, který již avizuje další vědeckotechnická revoluce - Průmysl 4.0. V opačném prrípadě může nastat generační propad, kde nebudou některé následující generace schopné adekvátně ovládat dostupné stroje a české školství bude vychovávat méně kvalitní pracovníky pro trh práce. Z těchto důvodů se domníváme, že zvolené téma disertační práce je velmi aktuální, bude př́nosem pro české školství, ekonomiku a konkurenceschopnost ČR. 


\section{Přehledová studie}

Tématem přehledové studie je zmapovat problematiku výuky programování počítačem ř́izených strojů na druhém stupni základních škol v rámci Technické výchovy. Zmapovat, jaké stroje jsou př́padně vhodné pro žáky základních škol, jak z pohledu schopnosti porozumět dané problematice, ale zároveň zjistit i efektivitu takové výuky. Zda se již některý autor nezabýval výzkumem zaměřeným na téma: Do jaké míry je výuka počítačem řízených strojů efektivní z pohledu vzdělávacího stupně. Především, zda je vhodné tuto problematiku vyučovat na základní škole, nebo ji ponechat až na technicky zaměřené stř̌ední školy, př́padně zda existuje studie, která řeší vhodnost výukového rozsahu na ZŠ a co ponechat na vhodně zaměřené SŠ.

Cílem přehledové studie není se zabývat pouze programováním a jeho vhodností na základní škole. Podobných studií již bylo sepsáno mnoho, výsledkem je, že se již delší dobu programování - algoritmizace vyučuje na druhém stupni Ž̌. Dokonce se stále více objevuje nejen na prvním stupni ZŠ, ale i v předškolním vzdělávání.

Smyslem přehledové studie je nalézt komplexní pohled na ucelenou problematiku programování počítačem rrízených strojů a vhodnost, případně metodika výuky na základní škole.

\subsection{Rešerše}

Při stanovení klíčových slov pro vyhledávání již výzkumných podkladů jsem se zaměřil na české školství, ve kterém se v blízké době očekává změna RVP v oblasti technické výchovy, tj. př́pravy žáků na život, ve kterém bude hrát značnou roli robotika a řízení strojů počítačem rrízených.

Technická výchova zde byla po mnoho let od roku 1989 značně opomíjeným tématem a nepovažovala se za podstatnou. Až vývoj v posledních letech se stále více začíná soustředit zpět na potřebu se této problematice více věnovat. Dokonce stále více sílí hlasy, jež se odkazují na Průmysl 4.0. S ohledem na výše uvedené bude zapotřebí se začít opět věnovat problematice technické výchovy, která patrně nebude v podobě jako před rokem 1989. Kromě dovedností v oblasti základní manuální zručnosti bude potřeba se věnovat novým vývojovým trendům $\mathrm{v}$ oblasti průmyslu. Především se tak jedná o problematiku programování a řízení počítačem řízených strojů. 
V ČR se touto problematikou nyní zabývá (Dostál, 2018), který se snaží v publikaci „Očekávané výstupy učení pro vzdělávací oblast Člověk a technika pro 2. stupeň základních škol“ popsat očekávané výstupy a oblasti, na které bude potřeba co nejdříve připravit žáky základních škol.

\subsection{Klíčová slova}

Při zmapování problematiky výuky programovatelných strojů na základních školách, bylo potřeba stanovit vhodná klíčová slova, na základě kterých je teprve možné vyhledávat informace v podobě vhodné literatury, studií, odborných časopisů atd.

Pokud budu vycházet $\mathrm{z}$ výše uvedené publikace „Očekávané výstupy učení pro vzdělávací oblast Člověk a technika pro 2. stupeň základních škol,“ objevuje se v kapitole „Tematický celek: technické činnosti a práce s materiálem“ pojem počítačem řízené stroje jako jsou 3D tisk, počítačem ovládané obrábění, laserové gravírování a dělení materiálů. Vzhledem k tomu, že oblast ČR je z pohledu světového měřítka značně malá a omezená, stanovil jsem si klíčová slova nejprve v českém jazyce, ale také jsem je vhodným způsobem přeložil do anglického jazyka. Zároveň je potřeba připomenout, že některé pojmy nelze úplně přesně přeložit, ale je potřeba respektovat místní označení, především pak systém vzdělávání ve světě, tj. označení škola atd.

Tab. č. 1: Přehled klícových slov.

\begin{tabular}{l:l}
\hline Klíčová česká slova: & Klíčová zahraniční slova: \\
\hdashline CNC soustruh ve výuce & CNC Mills in the classroom \\
CNC frézka ve výuce & CNC Cutter in the classroom \\
3D Tiskárna & 3D Printer \\
technické vzdělávání na základních školách & technical education in primary school \\
stroje & machines \\
technika & technics \\
inženýrství & engineering \\
matematika & mathematics \\
algoritmizace & algorithmization
\end{tabular}

Pro počítačem řízené stroje se více setkáváme s pojmem CNC - Computer Numeric Control. Tento pojem je tak znám i ve světě. Dalším úskalím překladu 
je především vzdělávání. U nás máme pojem druhý stupeň základního vzdělávání, ale v zahraničí, především pak v USA, je potřeba si uvědomit, že vzdělání na střední škole je označováno jako inženýrské, tj. vysokoškolské. Tím je možné se v doslovném překladu do češtiny setkat s pojmem předškolní inženýrské vzdělání.

\subsection{Vyhledávání teoretických zdrojů}

Níže uvedená tabulka se zabývá přehledem zkoumané literatury, jež se váže na problematiku výuky počítačem řízených strojů u nás v ČR.

Tab. č. 2: Přehled třídění teoretických př́istupů autorů v ČR.

\begin{tabular}{l|l|l|l}
\hline Autor & Rok pub. & Problematika & Idroj \\
\hdashline J. Dostál, A. Hašková, & 2017 & Technické vzdělávání na základních školách v kontextu & NPKK \\
$\begin{array}{l}\text { M. Kožuchová, J. Kopáč, } \\
\text { M. Ďuriš, J. Honzíková }\end{array}$ & & společenských a technologických změn & \\
\hdashline J. Dostál & & & \\
\hdashline $\begin{array}{l}\text { P. Simbartl, J. Honzíková, } \\
\text { J. Krotký }\end{array}$ & 2020 & Rozvoj technické gramotnosti za pomocí CNC strojü. & Trendy ve vzdělávání, \\
\hline
\end{tabular}

Níže uvedená tabulka se zabývá přehledem zkoumané literatury, jež se váže na problematiku výuky počítačem řízených strojů v zahraničí.

Tab. č. 3: Přehled třídění teoretických přístupů autorů v zahraničí.

\begin{tabular}{|c|c|c|c|}
\hline Autor & Rok pub. & Problematika & Zdroj \\
\hline D. Lyn, P. Hudson, L. Dawes & 2013 & $\begin{array}{l}\text { Engineering-Based Problem Solving in the Middle School: } \\
\text { Design and Construction with Simple Machines }\end{array}$ & \begin{tabular}{|c} 
J-PEER \\
\end{tabular} \\
\hline J. Stebila & 2015 & $\begin{array}{l}\text { Inovatívne vyučovacie metódy a ich využitie v technickom } \\
\text { vzdelávaní }\end{array}$ & Knihovna ZČU \\
\hline $\begin{array}{l}\text { S. S. Guzey, T. J. Moore, } \\
\text { M. Harwell }\end{array}$ & 2016 & $\begin{array}{l}\text { Building Up STEM: An Analysis of Teacher- Developed Engi- } \\
\text { neering Design-Based STEM Integration Curricular Materials }\end{array}$ & J-PEER \\
\hline $\begin{array}{l}\text { M. Dyehouse, A. L. Santone, } \\
\text { Z. Kisa, R. L. Carr, R. Razzouk }\end{array}$ & 2019 & $\begin{array}{l}\text { A Novel 3D+MEA Approach to Authentic Engineering Educa- } \\
\text { tion for Teacher Professional Development: Design Principles } \\
\text { and Outcomes }\end{array}$ & J-PEER \\
\hline P.J. Weinberg & 2019 & $\begin{array}{l}\text { Assessing Mechanistic Reasoning: Supporting Systems } \\
\text { Tracing }\end{array}$ & J-PEER \\
\hline S. Némethová, M. Mrázek & 2020 & $\begin{array}{l}\text { Trendy ve vzdělávání 2020: Programovanie CNC strojov - je } \\
\text { to skutočné programovanie? }\end{array}$ & $\begin{array}{l}\text { Trendy ve vzdělá- } \\
\text { vání, } 2020\end{array}$ \\
\hline
\end{tabular}




\section{4 České zdroje}

Na prvním místě jsem se na vyhledávání inkriminované problematiky zaměřil na ČR, jako domácí oblast. Na základě stanovených klíčových slov jsem začal vyhledávat vhodné podklady. Spousta nalezených podkladů (viz tabulka Přehled třídění teoretických zdrojů) se primárně týkala prodeje různých strojů, jak v průmyslovém provedení, tak i v didaktické úpravě vhodné pro potřeby výuky. Bohužel se tyto nabídky zaměřovaly na prodej, ale nejednalo se o komplexní nabídku, např́iklad s možnými úkoly atd. V žádném případně se nejednalo o jakékoliv zkoumání př́ípadné vhodnosti či efektivity takové výuky na konkrétním vzdělávacím stupni.

\subsection{1 Člověk a technika}

Autor (Dostál, 2018) se zde zaměřuje na očekávané výstupy technické výuky na ZŠ ve čtyřech oblastech:

- Technická kreativita

- Technické činnosti a práce s materiálem

- Řemeslo a technická profese

- Byt dům a zahrada

Z pohledu programování strojů je pro nás zajímavá druhá kapitola zabývající se technickými činnostmi a prací s materiálem. Nejedná se pouze o využití ručního nářadí, ale autor zde zmiňuje i problematiku počítačem řízených strojů. Jak jsme již v dnešní době svědky, použití 3D tiskárny v technické výchově.

Jako daleko zajímavější je potřeba vnímat zmínku o dalších strojích jako je obrábění a př́ípadné gravírování s dělením materiálu s využitím technologie laseru. Autor zde neuvádí přesný typ stroje na obrábění, ale lze usuzovat, že se jedná o soustruh a frézku. Uvedené stroje jsou v souvislosti s obráběním nejčastější i v technické praxi. Z pohledu výuky na ZŠ a bezpečnosti práce si úplně nelze představit práci s laserem na úrovni dělení materiálů, kde je zapotřebí využití laseru o nesrovnatelně vyšším výkonu oproti gravírování.

Pokud se budeme na danou problematiku počítačem řízených strojů dívat více z pohledu přípravy žáků na možné budoucí povolání, technických možností ZŠ a předpokládaného Průmyslu 4.0, bude ve výuce vhodnější použít obráběcí stroje, prrípadně 3D tisk, nebo dělení materiálu technologií laseru? Autor (Dostál, 2018) ve své podkladové studii nikterak detailně nerozvijí vhodnost konkrétní 
technologie, pouze poukazuje, že kromě dnes značně rozšířených 3D tiskáren je potřeba se zaměřit i na obrábění kovů, př́ípadně manipulaci s materiály.

Ostatní kapitoly (Dostál, 2018) jsou pro účely zkoumání efektivity programování méně vhodné, ale pro celkovou výuku Technické výchovy jsou podstatné. V první kapitole „Technická kreativita“ se žáci zaměřují na představivost, kreativitu a schopnost si představit výrobek dle technické dokumentace. Výuková činnost je zde více zaměřená na stavebnice a polotovary. Nutně se nemusí jednat pouze o mechanické sestavování, ale i o prvky elektrotechniky, robotiky atd. Technická činnost a práce s materiálem je kapitola pro nás z pohledu programovatelných strojů podstatná, autor zde zmiňuje některé stroje, které považuje za podstatné ve výuce na ZŠ. Předposlední kapitola se zabývá problematikou Řemeslo a technická profese. Jedná se o problematiku, jež má žákům přiblížit druhy řemesel a náplň jejich činností. Výsledkem je představa žáků o jednotlivých řemeslech, stř̌edních školách a o možnostech budoucího uplatnění na trhu práce, případně o možnostech dalšího studia. Tento výukový celek lze srovnávat s dnešním celkem RVP Svět práce. Poslední kapitolou je Byt dům a zahrada. Tato kapitola nejen spojuje základní technické dovednosti v oblasti práce s materiálem, ale žákům ukazuje i další oblasti jako je kultura bydlení, péče o zahradu, pěstování nejen okrasných, ale i užitkových plodin. V neposlední řadě se zaměřuje na problematiku ekologie, environmentálního chápání a udržitelného rozvoje.

Technické vzdělání v kontextu existujících kutikulárních dokumentů a nových společenských a technologických výzev - jedná se o první kapitolu, jež primárně formuluje potřeby technického vzdělání, dle současných společenských požadavků např́ič celým vzdělávacím systémem od mateřské školy, až po terciální technicky zaměřené vzdělávání. Autor zde porovnává i snahy o změnu vzdělávání např́klad v Německu, př́ípadně USA. Upozorňuje na potřebu reflektovat společensko-technicko-hospodářské změny a vycházet vstříc požadavkům 21 . století.

Komparace podoby realizace technického a prakticko-činnostního vzdělávání se zahraničím - je další kapitolou kde autor kritizuje současný stav, kdy mladá generace nemá mnohdy základní schopnost chápání, jak fungují mnohé technické systémy, natož schopnosti opravit mnohdy jednoduché věci. Poukazuje zde na určité opovržení v minulých letech nad smysluplností Technické výchovy. Způsob uvažování, kdy stroje za nás vše udělají a vyřeší je mylný. Je potřeba opět mladou generaci vést $\mathrm{k}$ technickým schopnostem, $\mathrm{v}$ této souvislosti zde uvádí pojem „technická a inženýrská gramotnost“. 
Role vyučovacího předmětu Technika v profesní orientaci žáků - v této kapitole se autor zaměřuje na problematiku povolání a na to, jakou zde hraje roli předmět Technika. Autor zde vysvětluje, že každá práce je př́nosem bez ohledu na druh, či požadovanou výši vzdělání. Podstatou je pochopení, že společnost potřebuje všechny profese. Samozřejmě jsou zaměstnání s rozdílnou fyzickou a intelektovou náročností, ale přesto všechna povolání společnost potřebuje. Výsledkem edukačního procesu pro žáky ZŠ, v rámci vzdělávání, by měl být vytvořený postoj úcty k ostatním pracovníkům bez ohledu na jejich společenské postavení.

Technika není informatika ani fyzika - autor zde v podstatě přiznává, že technika je mnohem komplexnější předmět, který klade na žáky mnohem širší nároky, než informatika či matematika. Technika v sobě zahrnuje nejen znalosti teoretické, především z oblasti materiálů, ale i informatiky, matematiky a fyziky. Na Slovensku se např́íklad pokusili někteří autoři (Ďuriš, Pavelka, Kozík, Stebila, 2015) více propojit výuku matematiky a informatiky, jelikož algoritmizace v matematice a logické uvažování je podobné jako informatické myšlení. Technika v sobě spojuje více předmětů a nelze ji vyučovat naprosto samostatně, a ani ji nelze nahradit jedním rozsáhlým předmětem. Technika je tak předmět, který v sobě spojuje spoustu mezipředmětových témat především v oblasti matematiky, fyziky a informatiky.

Podstatné aspekty kurikulárního plánování - autor zde naráží na problematiku českého třídění kurikula na samostatné předměty, zatímco technika by měla být spíše chápána jako předmět, jež spojuje více oblastí. Mnohé teoretické vědní obory utvářejí informace o fungování věcí okolo nás, ale předmět technika by měl tyto znalosti propojovat a dokázat tak žáky naučit tyto znalosti aplikovat.

Technika a vzdělávání žáků se speciálními vzdělávacími potřebami na úrovni základní školy - v současném okamžiku asi nejdiskutovanější téma dnešního školství. Autor zde uvádí, že technická výchova je v podstatě pro všechny žáky. Je však třeba respektovat požadavky každého jednotlivého žáka a tomu výuku přizpůsobit.

Technika a vzdělávání žáků nadaných a mimořádně nadaných - jako jsou ve třídách žáci se speciálními vzdělávacími potřebami, nesmíme zapomínat ani na žáky mimořádně nadané. Pokud se jim nebudeme věnovat, přestane je vzdělávání bavit, ztrácí se motivace a dochází ke snížení školní výkonosti. Bohužel se na tuto problematiku v současné době často zapomíná a velké úsilí se věnuje žákům se speciálními vzdělávacími potřebami. Autor zde poukazuje na potřebu se takovým žákům též věnovat individuálně a vytvářet takové podmínky výuky, které naopak povedou $\mathrm{k}$ jejich rozvoji. 
Shrnutím jednotlivých kapitol a představy autora o výuce Technické výuky na ZŠ je patrná snaha vypořádat se s vývojem dnešní doby. Na jedné straně nezapomínat na fundamentální znalosti a dovednosti, ale na druhé straně přidávat prvky moderní doby a potřebu se připravit na expanzi počítačem řízených strojů. Ačkoliv se může zdát, že poslední zmíněná problematika bude především záležitostí průmysl, nemusí to být v budoucnu úplně pravda. Počítačem řízené stroje mohou být doslova v každé domácnosti, dnes se již objevují první, jako např́klad automatické pračky programovatelné skrze smartphony, ale i inteligentní elektroinstalace domácností, např. Loxone. V oblasti strojů, např́íklad 3D tiskárny, laserové gravírovačky a podobně, nebudou v domácnostech př́liš často rozšířené, jelikož jejich činnost není pro běžný chod domácnosti zásadní. Autor poukazuje na opětovnou potřebu se tomuto předmětu v základním vzdělávání daleko hlouběji věnovat tak jako dříve, jen s ohledem na společensko-technicko-hospodářské požadavky 21. století.

\subsubsection{Technické vzdělávání na Základních školách v kontextu společenských a technologických zmèn}

Kolektiv autorů (Dostál, Hašková, Kožuchová, Kopáč, Ďuriš, Honzíková 2017) se zde opírá o předpokládané potřeby, které přinesou společenské požadavky v 21 . století. Především se jedná o nástup robotizace na nejnižší úrovni. Nahrazení jednoduchých činností člověka, a nejen $\mathrm{v}$ průmyslu, který napadne jako první většinu z nás, ale např́klad i v zemědělství. Autoři se v této souvislosti zmiňují, že v důsledku robotizace nedojde $\mathrm{k}$ nárůstu nezaměstnanosti, jak by se mohlo na první pohled zdát. Ve skutečnosti dojde k přesunu pracovníků na nová pracovní místa. V současném okamžiku není úplně jasné, jaká bude náplň uvolněných pracovníků, ale lze předpokládat, že rozvoj robotizace přinese nová uplatnění. Zároveň je třeba počítat s novými nároky, schopnostmi, technickou představivostí, uměním programovat atd. Tyto uvedené požadavky kladou do budoucna další nároky na edukační proces v základních a středních školách. Samozřejmě se nejedná jen o žáky, ale i učitele.

Autoři zde vycházejí z potřeby najít vyvážený vztah mezi schopnostmi ovládat, případně porozumět technice, jež je $\mathrm{v}$ dnešní době stále více propojována s výpočetní technikou. Rozvoj techniky však nemusí být nutně motivací pro jedince k pokusu technice porozumět, ale spiše se jí naučit ovládat, respektive ji využívat. Nejde jen o to, aby byl jedinec nadšený vlastní technikou, ale dokázal techniku využívat a ovládat. Ve svém důsledku si žák vytváríi kritické myšlení a je schopen se rozhodovat o svém budoucím povolání, které pochopitelně nemusí být nutně technického směru. 
Z pohledu edukačního procesu je potřeba počítat se způsobilostí žáků zvládat běžné životní situace spojené s využitím techniky, jež nás stále více začínají obklopovat. Vzdělávací potřeby je tak možné nejlépe vyjádřit ve vzdělávacích cílech výuky. Výše uvedení autoři vyzdvihují pojem jako technické myšlení, tvořivost a prostorová představivost. Schopnost tvořit a představovat si, je multifaktorový děj, který je nezbytný pro správné vnímání a případné chápání techniky. Autoři zde zmiňují i problematiku hodnocení a motivace, ale $\mathrm{v}$ tomto prrípadě se jedná především o pedagogicko-psychologické disciplíny. $\mathrm{V}$ každém př́padě motivace závisí nejen na dispozicích žáka, na probíraném učivu, ale i na způsobu hodnocení. To by mělo být komplexní a nemělo by se zaměřovat pouze na dílčí ćásti, ale více na celek, tj. schopnost žáka vyřešit úkol jako komplexní výsledek.

Jako velice důležité autoři vnímají úbytek dostatečně erudovaných vyučujících na školách, kteří jsou schopni problematiku techniky vyučovat, dokonce jej nazývají jako „ohrožený druh živočicha“. Určitou příčinou tohoto stavu může být jistá nejistota a zpochybnění významu Technické výchovy v RVP a z toho plynoucí ŠVP jednotlivých škol. Již v současném okamžiku není celá náplň RVP pro školy zavazující a mnohé tak nedisponují potřebným vybavením, například dílny, pozemky atd. Je patrné, že význam předmětu Technická výchova by měl být minimálně postaven na úroveň ostatních prrírodovědných předmětů jako např́klad Fyzika atd. Zároveň musí ve společnosti vzniknout poptávka po schopnostech, které tento předmět pokrývá a tím celkově dojít k navýšení společenské prestiže tohoto předmětu.

Autoři se též zabývají problematikou a efektivitou využití moderní edukační techniky ve vzdělávání techniky, jako je interaktivní tabule a stále více oblíbené tablety. Použití inkriminované techniky ve výuce zatraktivní, a u žáků vyvolá aktivizaci. Především pak umožní vytvářet různé pohledy na výrobek, zadání, technickou dokumentaci atd. Žákům je případné zadání, či vyučovaná problematiky více zobrazována vizuálně i s možností virtuální reality. Didaktické pomůcky v podobě funkčních modelů je možné částečně nahradit v dnešní době virtuální a rozšriřenou realitou. $V$ této souvislosti je zmíněna i problematika $3 \mathrm{D}$ tisku. Ačkoliv nelze předpokládat potřebu využití této technologie doslova v každé domácnosti, je pojetím ovládání a př́pravy tisku podobná CNC obrábění. Nemluvě o dalším využití v designu, prototypy atd. Vzhledem $\mathrm{k}$ finanční dostupnosti se tak jeví jako možná alternativa na edukaci, především na základních školách.

Patrně nejzajímavější částí je kapitola „Počítačem podporované experimenty $v$ technickém vzdělávání. "Autoři se zde zaměřili na pojetí dvouúrovňového kuri- 
kula slovenských škol. K získání potřebných znalostí žáků se jeví jako nejvhodnější využívat při výuce školní experiment. Žáka takový postup nejen motivuje, ale utváří u žáků představivost, kritické myšlení, sociální kompetence a mnoho dalších. Ačkoliv se autoři zabývají výzkumem významu výuky počítačem řízených strojů, nenachází se v kapitole žádné doporučení o jaký př́padný stroj by se mělo jednat. V každém případě je patrné, že vzdělávací směr SR v oblasti Technické výchovy je adekvátní dnešním společensko-vědním potřebám.

Závěrem je konstatování, že „je lidstvo na technice závislé“. V podstatě se nelze vrátit zpět, př́ípadně tuto skutečnost jakkoliv ignorovat. Ba naopak je potřeba si tento stav společnosti uvědomit a snažit se $\mathrm{v}$ edukačním procesu nalézt řešení jak budoucí generace vhodně připravit na život s technikou. At̉ už se bude jednat pouze o soužití, případně aktivní řešení v podobě profesního života.

\subsubsection{Trendy ve vzdělávání, 2020}

Článek autorů (Simbartl, Honzíková, Krotký, 2020) se zabývá problematikou „Rozvoje technické gramotnosti za pomoci CNC strojü “. Především se ve svém příspěvku zaměřují na potřebu zvládnout technologie $3 \mathrm{D}$ tisku a jeho důležitosti při rozvoji technického myšlení, na které navazuje problematika strojů CNC. Ačkoliv stroje CNC nelze očekávat $\mathrm{v}$ domácím použití, jedná se $\mathrm{v}$ dnešní době o naprosto běžnou záležitost v lehkém strojírenství.

Autoři vnímají problematiku 3D tisku jako základní seznámení žáků škol (především základních) s počítačem řízenými stroji. 3D tisk je v současném okamžiku finančně dostupný i pro většinu škol, díky čemuž se mohou žáci seznámit se základy řízení počítačem řízených strojů. Zároveň je tak možné stavět na takto vzniklých fundamentálních znalostech žáka pro složitější systémy jako jsou naprríklad CNC stroje atd.

Autoři zde vycházejí z předpokladu rozvoje průmyslu, především v automatizaci a autonomních systémů. Schopnost ovládat 3D tisk není cílem, ale začátkem pro pochopení složitějších systémů. Lze tak předpokládat, že do budoucna budou na populaci kladeny nároky se s těmito požadavky vyrovnat. $Z$ toho plyne potřeba se v rámci Technické výchovy této problematice věnovat nejen po technické stránce, ale komplexně v pojetí očekávané edukace. 


\subsection{Zahraniční zdroje}

V zahraniční lze nalézt mnohem více podkladů - studií, jež se zabývají inkriminovanou problematikou. S ohledem na nalezené podklady lze tvrdit, že si v zahraničí potřebu připravovat žáky na Průmysl 4.0 již dávno uvědomili a veškeré snahy ve vzdělávacích strategiích $\mathrm{k}$ tomu směřují.

Asi největším úskalím vyhledávání zahraničních zdrojů je poněkud jiné pojmenování vzdělávání a stupňů vzdělávání na rozdíl od ČR. Nestačí tak pouhý překlad, ale je potřeba bližší znalosti vzdělávacího systému ve světě.

\subsubsection{Programovanie CNC strojov - je to skutočné programovanie?}

Autoři (Némethová, Mrázek, 2020) se ve svém př́íspěvku v časopise Trendy ve vzdělávání (Trends in Education) zaobírají problematikou kutikulární reformy druhého vzdělávacího stupně v ČR. Přesněji se jedná o nově vznikající oblast Člověk a technika, ze které by měl vzejít nově vyučovaný předmět s názvem Technika. Autoři zde vycházejí $z$ analýzy podkladové studie (Dostál 2018). Úkolem připravovaného předmětu Technika by mělo být především seznámení žáků s technikou, například stroji, mechanická ústrojí atd., a v neposlední řadě i s programováním CNC strojů a případně PLC automatů, které tyto stroje rrídí.

Autoři řeší způsoby využití CNC strojů v praxi a tím potřebu tuto problematiku vyučovat, v rámci vzdělávacího procesu již na základních školách. CNC stroje jsou univerzálním zařízením, jež je schopné v průmyslu zajistit výrobu různých druhů základních součástek, ale i jejich vzájemné sestavovaní ve větší a složitější celky. Samotné CNC (computer numerical controlled) stroje jsou rrízeny PLC automaty (programmable logic controller) a zde je prostor pro vlastní programování, které může mít mnoho podob, dle druhu konkrétního automatu.

Autoři v souvislosti s programováním počítačem řízených strojů zmiňují vztah mezi informatikou a programováním. Popisují pojem programování především jako algoritmus, tj. předem naplánované po sobě jdoucí úkony, na jejichž konci je výsledek, například výrobek atd. Přímo zde nezmiňují potřebu průřezových témat předmětů Informatiky a Techniky. $\mathrm{V}$ další části příspěvku se zaměřují především na základní principy programování, kde vyzdvihují potřeby dostatečně porozumět funkci stroje. Bez řádného chápání pohybů a technologického postupu, algoritmu, není programátor schopen kvalitně, ne-li vůbec, zvládnout programování inkriminovaného stroje. $V$ další části se autoři již zaměřují obecně především 
vlastní technice programování, nikoliv didaktice. Pouze zmiňují potřebu vše vyučovat od základních například jednoúčelových strojů, až po složité víceúčelové a univerzální stroje.

Celá problematika je shrnuta na potřebu dobré znalosti konstrukce stroje a jeho činnosti - pohybů. Teprve na základě dokonalého porozumění technologii a stroji, je možné, aby začal žák (programátor) s vlastním programováním. Vlastní programování se může dle použitého softwaru lišit, avšak základní postupy, algoritmy jsou vždy stejné, liší se pouze způsob zápisu programu, případně grafické uspořádání programu.

\subsubsection{Inovatívne vyučovacie metódy a ich využitie v technickom vzdelavaní}

Publikace je primárně zaměřená na vyučovací metody $\mathrm{v}$ předmětech $\mathrm{s}$ výukou techniky. Autor (Stebila, 2015) zde uvádí různé přístupy v několika zemích EU. Např́klad v ČR se jedná o předmět Technická výchova a na Slovensku Technika a technologie. Dále se zmiňuje i o způsobu výuky ve skandinávských zemích, především pak ve Finsku.

Ačkoliv se autor nezabývá specificky problematikou programování počítačem řízených strojů, klade v publikaci důraz na potřebu technického vzdělávání žáků již v základním vzdělávání. Především se má jednat v mladším věku o rozvíjení jemné motoriky při činnostech $\mathrm{v}$ dílnách, které má pokračovat adekvátně s věkem žáka. Výsledkem jsou kompetence v oblasti technické zručnosti, jež odpovídá věku žáka, ale též v oblasti technické představivosti, schopnosti samostatně tvořit a vytvářet pracovní postupy - algoritmy. V této souvislosti autor (Stebila, 2015) klade důraz na očekávané potřeby společnosti především v oblasti strojů, kde dojde k nárůstu požadavků na technicky orientované pracovníky.

Zároveň je v publikaci zmiňována propojenost ICT a výuky techniky. Větší část této problematiky je věnována především ICT jako podpora učitele ve výuce a tím i inovativní metody výuky, které vedou k větší efektivitě výuky. Cílem takové snahy je zvýšení efektivity transferu vědomostí, ale i získání hlubšího porozumění vyučované problematiky a $\mathrm{v}$ neposlední řadě vytvoření aktivního př́stupu žáka k výuce. 


\subsubsection{Engineering-Based Problem Solving in the Middle School: Design and Construction with Simple Machines}

Studie autorů (English, Hudson, Dawes, 2013) poukazuje na jednoznačné požadavky společnosti zvýšit technické kompetence žáků základních, ale i středních škol. Již v základním vzdělávání je potřeba se věnovat činnostem s jednoduchými stroji, dokázat pochopit základní principy a postupy, které budou následně žáci schopni aplikovat nejen v běžném životě, ale i v budoucím profesním životě. V textu se vyskytuje výraz „vědecky gramotnější občan,“ jako hlavní cíl budoucího vzdělávání.

Př́kladem je školství v Austrálii, kde bylo zavedeno nové kurikulum z matematiky, prrírodních věd a technologie. Tamní řešení si od nového kurikula slibuje obecné zvýšení povědomí o technice a strojích. Má za to, že dojde k vytvoření společnosti, ze které snáz vzejdou budoucí techničtí specialisté, technici, řemeslní, vědci atd. Inkriminované kurikulum řeší nasazení nových vzdělávacích plánů již na druhém stupni základního vzdělávání, na které přímo navazuje střední vzdělávání, samozřejmě dle oborového zaměření.

Dokument se dále zaměřuje na zkoumání schopností i dětí na úrovni prvního stupně vzdělávání, kdy chápání jednoduchých strojů vede k jejich rozvoji a schopnostem samostatně navrhovat jednoduché pracovní postupy, schopnost se orientovat $\mathrm{v}$ rozsahu použitého materiálu a schopností samostatné realizace a plánování. Uvedené znalosti žáků přináší efektivní řešení jednoduchých případů v životě, např́klad při základní údržbě domu, domácnosti a podobně.

Autoři kladou důraz na mezipředmětové vztahy, protože nepovažují technickou př́pravu za samostatnou, oddělenou, ale naopak vnímají tuto problematiku jako propojenou především s matematikou a informatikou. Dále je zde upozorněno na potřebu spolupráce při činnostech na strojích. Žáci pracují v malých kolektivech, kde se učí kooperaci a zároveň společnou diskusí přispívají k efektivnějšímu chápání principů strojů. Názornost, grafické znázornění, využití vhodných didaktických pomůcek zvyšují pochopení a vlastní představu žáků o funkcionalitě systémů. Podstatou budoucího rozvoje a pochopení složitějších systémů je pochopení základních principů jednoduchých strojů.

Shrnutí obsahu dokumentu jasně směřuje k potřebě se detailně věnovat technické výchově a porozumění jednoduchým strojům. Zároveň je zde uváděno, že pochopení základních principů vede v budoucnu k snadnějšímu porozumění složitějších zařízení a schopnosti samostatně takové stroje a zařízení kreativně 
konstruovat. $\mathrm{V}$ dokumentu se však nenachází přesná odpověd’ na otázku, co jsou jednoduché stroje a navíc řízení takových strojů není realizováno s požitím počítače. Přesto potřeba se této oblasti věnovat je opakovaně uváděna.

\subsection{4 a Novel 3D+MEA Approach to Authentic Engineering Education for Teacher Professional Development: Design Principles and Outcomes}

Autoři (Dyehouse, Santone, Kisa, Carr, Razzouk, 2018) zde uvádějí STEM - jako vzdělání v oblasti vědy, matematiky, techniky, př́rodních věd. Národní rada výzkumu (NAE \& NRC, 2014) definuje STEM jako „soudržnost centrálních konceptů napříč reprezentacemi matematiky a vědy, inženýrskými objekty, designovými a konstrukčními aktivitami a sociálními strukturami ve třídě“.

Studie poukazuje na problém, kdy vyučující zpravidla vyučují předměty jako matematika, technika a fyzika odděleně a neuvědomují si tak společné mezipředmětové vztahy. Tento problém vede k izolovanému vnímání vyučované látky a nepochopení provázanosti mezi vyučovanou látkou v jednotlivých předmětech. Schopnost vyučujících, kteří dokáží chápat výuku STEM jako celek, dokáží vytvořit kutikulární mezipředmětové aktivity a mohou implementovat tyto činnosti do výuky ZŠ a SŠ.

Studie dále poukazuje na několik klíčových bodů - standardů, pomocí kterých lze definovat myšlenky a postupy při vzdělávání.

- Definování problému a vznik otázky.

- Využití modelů.

- Naplánování postupu.

- Analýza problému.

- Využití algoritmizace, matematických výpočtů $\mathrm{k}$ řešení problému.

- Argumentace řešení, návrhy řešení a postupů.

- Ověření argumentů a jejich obhajoba.

- Shrnutí výsledků a jejich předání k dalšímu využití - zveřejnění atd.

Výše uvedené body popisují postupy při zkoumání a řešení problémů nejen $\mathrm{v}$ př́rodních vědách, ale i při řešení technických problémů a případně navrhování řešení a konstruování strojů.

Práce poukazuje na potřebu učitele v problematice technického vzdělání dále se vzdělávat, tzn. nabídnout jim nejen odpovídající znalosti, ale i metody vzdělávání s možností vzájemného propojení vyučovaných předmětů. Studie zmiňuje větší úspěšnost u vyučujících v případě, že jsou při dalším vzdělávání více „vtaže- 
ni“ do vlastního výzkumu, kdy vyučovanou problematiku „prožívají.“ Vhodným nástrojem při př́pravě vyučujících je i jejich přímá účast na výzkumech ve vědeckých laboratořích, kde své poznatky mohou přenášet přímo do výuky. Učitelé tak dokáží vhodněji přizpůsobit stávající výukové materiály, prrípadně vznikají nové a zajímavější, jež lépe aktivizují žáky ve výuce. Zda bude takový postup úspěšný, značně závisí na motivaci nejen žáků, ale i učitelů.

Studie zmiňuje nejen vzdělávací postupy, potřeby vzdělávání vyučujících, jejich př́ípadné zapojení do výzkumných činností v laboratořích, stále se opakující potřeby motivovat všechny skupiny vzdělávání, ale také zdůrazňuje skupinovou činnost. Při výuce jsou tak vytvořeny skupiny - týmy žáků, kteří společně řeší vzniklý úkol. Nejde tak jen o nalezení vhodného pracovního postupu, ale i o schopnost kooperace a komunikace ve skupině. Výuka v takovém př́padě představuje nejen spolupráci ve skupině, výměnu informací a názorů, ale i prvky soutěživosti mezi jednotlivými týmy. Vyučující v takovém případě hraje především roli koordinátora, př́padně žáky motivuje a usměrňuje. Není tak nucen zásadním způsobem zasahovat do vlastního procesu vzdělávání. Výsledkem tohoto způsobu výuky je nejen nalezení řešení vlastního úkolu, ale především schopnosti analyzovat problém, hledat postup řešení a spolupracovat ve skupině při výměně informací, názorů atd.

Inkriminované postupy byly původně zaměřené na výuku ZŠ, ale jak uvádí studie, jsou stále více využívány i na SŠ a dokonce v dnešní době existuje na Floridě USA oficiální web www.cpalms.org, kde lze nalézt spousty úkolů pro učitele.

\subsubsection{Assessing Mechanistic Reasoning: Supporting Systems Tracing}

Schopnost uvažovat nad funkcionalitou a principy strojů je jedním z klíčových kompetencí v chápání a řešení technických a matematických problémů. Autor studie (Weinberg, 2018) se zaměřuje na výzkum schopnosti chápat stroje jako soubor pák, převodů atd., jejichž vzájemná funkcionalita má předem daný algoritmus. Celková složitost a rozsah stroje má pak vliv na schopnost porozumění danému problému.

Studie uvádí, že dokonalé pochopení funkcionality stroje je základem dalšího rozvoje a řešení př́ípadných úkolů. Uvádí, že na základních školách by měl být kladen dưraz na chápání základních principůa, aby bylo možné následně tyto znalosti využít v dalším, tj. středoškolském vzdělávání. Dokument argumentuje potřebou chápat problémy konzistentně vědecky, matematicky a technicky. Výsledkem je řešení více technických postupů, nikoliv pouhé omezení na jedno řešení. $V$ řešení 
jakýchkoliv úkolů v mnoha disciplínách činností zpravidla neexistují pouze jedno řešení, ale obvykle se nabízí více řešení. Konkrétní analýza, případně řešení, mají vycházet $\mathrm{z}$ funkcí jednodušších základních částí a vést postupně ke složitějším celkům a $\mathrm{k}$ jejich porozumění.

Studie uvádí, že mnoho žáků se při hledání řešení soustředí na funkci základních částí, které dokáží mnohdy detailně popsat, ale dále nejsou schopni se soustředit na další části jako celek a nejen jim porozumět, ale dokázat je př́padně i rozvíjet. Studie uvádí, že v roce 2012 byl vyvinut systém základních činností zaměřených na základní páky a mechanické prvky, u kterých následně zkoumali schopnost formy porozumění a uvažování. Důraz je kladen na včasné pochopení dětí základních mechanických systémů, ve kterých hrají roly síly, vektory, tahy a geometrie. $Z$ výše uvedeného vyplívá, že je potřeba studenty nejdřive seznámit se základními principy mechanických převodů a pák, jako základ pro budoucí rozvíjení systémového myšlení, modelování, analýzy a následné schopnosti tvořit nové věci, spolupracovat a komunikovat v týmu. Studie se zabývá individuální analýzou uvažování nad funkcionalitou jednoduchých pák.

Vlastní studie zkoumá kognitivní aspekty se zaměřením na analýzu a nalezení řešení v kontextu jednoduchých strojů. Uvádí potřebu se zaměřit na výuku jednoduchých strojů, s cílem pochopení základních principů, jež je potřebný pro případné budoucí technické uplatnění.

\subsubsection{Building Up STEM: An Analysis of Teacher- Developed Engineering Design-Based STEM Integration Curricular Materials}

Autoři (Guzey, Moore, Harwell, 2016) se v rámci výzkumu soustředili na získání informací a následné aplikaci výukových programů v oblasti technické výchovy v základním vzdělávání v USA. Pro účely výzkumu spolupracovali se 48 učiteli, kteří během jednoho roku zpracovali a otestovali 20 nových výukových bloků.

V letech 2010 docházelo v USA k vyvolávání výzev pro reformu vzdělání v oblasti matematiky a techniky. Postupně se shodli Národní akademie inženýrství - NAE a Národní rada pro výzkum - NRC na potřebě zlepšení vzdělání v oblasti technických oborů. Celá tato problematika byla označena vysokou prioritou, jelikož se očekává do budoucna značný rozmach techniky a za tímto účelem bude potřeba mnoho pracovníků s technickým vzděláním. Výsledkem těchto kroků by mělo být: 
1. Zvýšení počtu studentů, kteří jsou schopni se věnovat pokročilejšímu vzdělání $\mathrm{v}$ oblasti STEM.

2. Rozšíření pracovní síly v oblasti STEM.

3. Zvýšit technickou gramotnost všech studentů v oblasti STEM.

Výsledkem výše zmíněných cílů by měla být vzdělanější populace v USA v oblasti STEM, která zaručí další udržitelný technický růst, tím i další růst ekonomiky a celkovou prosperitu USA včetně konkurenceschopnosti v zahraničí.

Přestože o problematice technického vzdělávání se diskutuje již mnoho let po celém světě a mnohé vlády zemí se snaží změnit vzdělávací kurikula v základním vzdělávání, začala se tato problematika řešit i nyní na federální úrovni USA. Otázkou tak není, zda začít populaci studentů v základním vzdělávání více vzdělávat v oblasti matematiky, přírodních věd a především pak v technických oblastech, ale jakým způsobem těchto cílů dosáhnout. Jaké vhodné postupy a metody zvolit, aby se dostavil očekávaný výsledek.

Přístup, který byl při vlastní prrípravě zvolen, byl v podstatě zajímavý tím, že se jej účastnilo 48 př́rodovědných učitelů a po dobu tři týdnů se společnými silami pokusili vytvořit vhodné výukové bloky, včetně postupů a metod výuky. Výsledkem byl vznik 20 výukových bloků v oblasti STEM.

Autoři studie se v této souvislosti zaměřili na dvě otázky:

1. Jaké jsou charakteristiky výukových bloků, jež vznikly ve spolupráci 48 př́rodovědných učitelů?

2. Existují určité rozdíly mezi výukovými bloky STEM, které integrují proces projektového vzdělávání s technickou vědou, matematikou a fyzikou?

Výsledkem studie není přesné stanovení konkrétních výukových bloků v oblasti technické výchovy STEM, ale soustředění se na vytvoření podpůrných materiálů pro profesní rozvoj učitelů, aby si tak mohli lépe osvojit a prohloubit znalosti v inkriminované oblasti. Učitelé potřebují možnosti pro osvojení si znalostí, výukových postupů a čas $\mathrm{k}$ implementaci nových učebních materiálů do výukových programů.

Programy osobního vzdělávání a profesního růstu učitelů se zaměřují na základní porozumění problematice a výukových dovedností. Mohou tak učitelům poskytnout postupy jak se sami vzdělávat a jak provádět integraci nových výukových oblastí se zaměřením na STEM do výuky.

Doporučením autorů je výzkum, který by se v budoucnu měl zaměřit na zpětnou vazbu učitelů, jakým způsobem se jim daří implementovat výukové bloky. 
Zmapovat jejich zkušenosti, př́ípadná úskalí a pozitiva, aby bylo možné vydat doporučení ostatním pedagogům, jak mají postupovat a volit vzdělávací strategii.

\section{Shrnutí přehledové studie}

Z pohledu ČR je potřeba si uvědomit, že se s problematikou programování počítačem řízených strojů zabývá méně autorů, nežli je tomu v zahraničí. Dle obsahu a rozsahu jednotlivých prací se však nejedná o méně kvalitní zdroje informací. Dokonce je zde patrný bližší pohled odpovídající českému školství a potřebám naší společnosti. Patrně nejvíce se dané problematice věnuje (Dostál, 2018) v Člověk a technika - podkladová studie k revizím RVP a dále jako spoluautor publikace Technické vzdělávání na základních školách v kontextu společenských a technologických změn, kolektiv autorů (Dostál, Hašková, Kožuchová, Kopáč, Duriš, Honzíková, 2017)

Všichni autoři se zde shodují na potřebě vychovávat mladou generaci techniků, kteří budou schopni obstát s rozvojem Průmyslu 4.0. Již dnes je patrné, že se bude jednat o rozmach kybernetiky, kde bude většina lidské činnosti nahrazena stroji, př́padně různými druhy manipulátorů. Zároveň autoři zmiňují i problematiku zaměstnanosti, přesněji, že náhrada lidské činnosti stroji nepřinese navýšení nezaměstnanosti, ale naopak začnou vznikat nové pracovní pozice, které si dnes jen stěží dokážeme představit. Na takto předpokládaný vývoj je potřeba již dnes připravit mladou generaci. V opačném př́padě nebude dostatek technických odborníků na různých pracovních úrovních a nebude možné adekvátně Průmysl 4.0 v ČR rozvíjet. Tím pochopitelně začneme zaostávat za světem a v konečném důsledku nebudeme ve světě konkurenceschopnými.

Nejedná se jen o vlastní výuku programování na ZŠ, ta je již dnes vyučována v rámci ICT a rozvíjí představivost, algoritmizaci atd. Autoři se, ale zaměřují na potřebu učit se programovat stroje, které jsou řízené počítačem. Člověk a technika - podkladová studie k revizím RVP (Dostál, 2018), ve své práci uvádí př́klady strojů, jež jsou pro tuto výuku na ZŠ vhodné: laserová gravírka, 3D tisk plastu, dělení materiálu laserem. Soudě dle př́kladů se nutně nejedná o specificky zaměřené prŕíklady strojů, ale spíše technicky a finančně dostupné stroje pro použití na Ž́.

Autoři se shodují v potřebě vyučovat $\mathrm{v}$ rámci technické přípravy nejen základní manuální činnosti a rozvíjet tak jemnou motoriku, ale s ohledem na budoucí vývoj se věnovat př̌edevším řízení - programování strojů, jež jsou řízeny počíta- 
čem. Autoři přesně nespecifikují, jaké stroje jsou nejvhodnější. Lze však usuzovat, že se $\mathrm{v}$ dnešní době jedná především o značně rozšsiřený $3 \mathrm{D}$ tisk, ale mohou to být i další zařízení, jako např́klad různé manipulátory, roboti, CNC stroje atd.

Zároveň se autoři nezabývají vhodností výuky programování na různých úrovních škol, především pak na ZŠ a SŠ. Primárně se věnují této problematice na ZŠ, ale v jakém rozsahu je taková výuka vhodná? Př́ípadně jak rozsáhlé mají být technické znalosti žáků v problematice programování strojů? Nabízí se otázka, zda následně nepokračovat $\mathrm{v}$ hlubší výuce žáků dané problematiky na specializovaných SŠ, kteří si takovou školu v rámci př́pravy na budoucí povolání zvolí.

U zahraničních zdrojů je patrné, že ve výuce programování počítačem řízených strojů mají již nyní autoři jasno. O potřebě připravovat žáky již na ZŠ nepochybují a další rozvoj na technicky zaměřených SŠ považují za nutný. Pochopitelně pro žáky, kteří si vhodně technicky zaměřenou školu zvolí. V současném okamžiku se spíše autoři zabývají, jak vhodně začlenit výuku do RVP, s jakými dalšími předměty ji případně propojit. Uvádějí, že se jedná především o provázanost technické výchovy, matematiky, fyziky a ICT. Tyto předměty by měly vhodným způsobem vytvořit požadované kompetence žáků.

Kromě legislativy a obsahu RVP se zaměřují ve světě na osobnost a kompetence učitelů, kde hledají způsoby, jak vhodně nalézt zájem vyučujících změnit své postoje. Vytvářejí se výukové materiály, podpůrné informace se snaží šírit do škol a podporovat nákup nových moderních strojů, na kterých se mohou žáci učit novým dovednostem.

Podíváme-li se globálně na uvedenou problematiku, je patrné, že o potřebě vyučovat a připravovat žáky na Průmysl 4.0 nikdo nepochybuje ve světě ani u nás.

V zahraničí mají již otázku, zda vyučovat počítačem řízené stroje zodpovězenou, mnohé vlády již obsah takového vzdělávání mají ve svých národních RVP a úsilí věnují na podporu metodiky výuky.

V ČR máme otázku, zda vyučovat programování počítačem ř́izených strojů již také vyřešenou, ale nyní není tato problematika dostatečně zapracovaná do RVP. Navíc školy nejsou na tuto potřebu dostatečně vybaveny. Samozřejmě s tím jsou spojeny i kompetence učitelů př́padně edukační materiály.

\section{Literatura}

Dostál, J., Hašková, A., Kožuchová, M., Kropáč, J., Ďuriš, M., \& Honzíková, J. (2017). Technické vzdělávání na základních školách v kontextu společenských a technologických změn. Univerzita Palackého v Olomouci. 
Dostál, J. (2018). Člověk a technika - podkladová studie k revizím RVP [podkladová studie]. NVU. NVU.

Dyehouse, M., Santone, A. L., Kisa, Z., Carr, R. L., \& Razzouk, R. (2018). A Novel 3D+MEA Approach to Authentic Engineering Education for Teacher Professional Development: Design Principles and Outcomes. Journal of Pre-College Engineering Education Research (J-PEER), 9(1), Article 4. https://doi.org/10.7771/2157-9288.1168

English, L. D., Hudson, P., \& Dawes, L. (2013). Engineering-Based Problem Solving in the Middle School: Design and Construction with Simple Machines. Journal of Pre-College Engineering Education Research (J-PEER), 3(2), Article 5. https://doi.org/10.7771/2157-9288.1081

Guzey, S. S., Moore, T. J., \& Harwell, M. (2016). Building Up STEM: An Analysis of TeacherDeveloped Engineering Design-Based STEM Integration Curricular Materials. Journal of Pre-College Engineering Education Research (J-PEER), 6(1), Article 2. https://doi.org/10.7771/2157-9288.1129

Némethová, S., Mrázek, M. (2020). Programovanie CNC strojov - je to skutočné programovanie?. In: Trendy ve vzdělávání. UPOL. roč.13, č.1.

Simbartl, P., Honzíková, J., Krotký, J. (2020). Rozvoj technické gramotnosti za pomoci počítačem ř́zených strojů. In: Trendy ve vzdělávání. UPOL. roč. 13, č.1.

Stebila, J. (2015). Inovatívne vyučovacie metódy a ich využitie v technickom vzdelávaní: vedecká monografia. Univerzita Mateja Bela v Banskej Bystrici, Fakulta prírodných vied.

Weinberg, P. J. (2018). Assessing Mechanistic Reasoning: Supporting Systems Tracing. Journal of Pre-College Engineering Education Research (J-PEER), 9(1), Article 3. https://doi. org/10.7771/2157-9288.1182 